\title{
Ice front change of marine-terminating outlet glaciers in northwest and southeast Greenland during the 21 st century
}

\author{
CHARLIE BUNCE, ${ }^{1,2}$ J. RACHEL CARR, ${ }^{1}$ PETER W. NIENOW, ${ }^{2}$ NEIL ROSS, ${ }^{1}$ \\ REBECCA KILLICK ${ }^{3}$ \\ ${ }^{1}$ School of Geography, Politics and Sociology, Newcastle University, Newcastle-upon-Tyne, UK \\ ${ }^{2}$ School of Geosciences, University of Edinburgh, Drummond Street, Edinburgh, UK \\ ${ }^{3}$ Department of Mathematics and Statistics, Lancaster University, Lancaster, UK \\ Correspondence: C. Bunce <c.bunce@sms.ed.ac.uk>
}

\begin{abstract}
The increasingly negative mass balance of the Greenland ice sheet (GrIS) over the last $~ 25$ years has been associated with enhanced surface melt and increased ice loss from marine-terminating outlet glaciers. Accelerated retreat during 2000-2010 was concentrated in the southeast and northwest sectors of the ice sheet; however, there was considerable spatial and temporal variability in the timing and magnitude of retreat both within and between these regions. This behaviour has yet to be quantified and compared for all glaciers in both regions. Furthermore, it is unclear whether retreat has continued after 2010 in the northwest, and whether the documented slowdown in the southeast post-2005 has been sustained. Here, we compare spatial and temporal patterns of frontal change in the northwest and southeast GrIS, for the period 2000-2015. Our results show near-ubiquitous retreat of outlet glaciers across both regions for the study period; however, the timing and magnitude of inter-annual frontal position change is largely asynchronous. We also find that since 2010, there is continued terminus retreat in the northwest, which contrasts with considerable inter-annual variability in the southeast. Analysis of the role of glacier-specific factors demonstrates that fjord and bed geometry are important controls on the timing and magnitude of glacier retreat.
\end{abstract}

KEYWORDS: arctic glaciology, glacier fluctuations, glacier mapping, remote sensing

\section{INTRODUCTION}

Since the early 1990s, the rate of ice loss from the Greenland ice sheet (GrIS) has accelerated in synchrony with both elevated air temperatures (e.g. Hanna and others, 2008, 2012b, 2013; Fettweis and others, 2013) and warmer ocean waters reaching marine margins (e.g. Murray and others, 2010; Straneo and others, 2012, 2016; Sutherland and Straneo, 2012). The average annual mass loss from the GrlS between 1991 and 2015 was $0.47 \pm 0.23 \mathrm{~mm}$ SLE (Van den Broeke and others, 2016) and was driven by negative surface mass balance (primarily the result of increased air temperatures, leading to enhanced surface melt) and increasing ice discharge from outlet glaciers (channels of fast flowing ice draining the ice sheet and terminating at a marine margin) (Meier and Post, 1987; van den Broeke and others, 2009; Post and others, 2011). These glaciers contribute to ice loss through enhanced retreat of the calving front (Meier and Post, 1987; Pfeffer, 2007; Post and others, 2011) and associated thinning and accelerated ice motion that further enhances retreat (Van der Veen, 2002; Pritchard and others, 2009; van den Broeke and others, 2009; Enderlin and others, 2014).

Understanding the patterns of retreat in the northwest and southeast regions of the GrIS is especially important because together, these regions currently contribute over $80 \%$ of the ice sheets total annual dynamic discharge (Enderlin and others, 2014) and are therefore important contributors to ice loss and overall ice-sheet mass balance. Outlet glaciers here have undergone rapid and variable changes in frontal position over the last $\sim 25$ years (e.g. Howat and others, 2008b; Moon and Joughin, 2008; Howat and Eddy, 2011; McFadden and others, 2011; Carr and others, 2013;
Murray and others, 2015). For example, in the southeast, accelerated retreat was detected between the mid-1990s (Rignot and others, 2004) and early 2000s (Howat and others, 2008a, b; Joughin and others, 2008a; Moon and Joughin, 2008). Retreat rates in the northwest did not accelerate until after 2005 (Moon and Joughin, 2008; Howat and Eddy, 2011; McFadden and others, 2011; Carr and others, 2013; Moon and others, 2015; Murray and others, 2015), which coincided with a slowdown in retreat rates in the southeast (Moon and Joughin, 2008; Howat and Eddy, 2011; Murray and others, 2015). Due to the variable nature of the timing and pattern of frontal change in these regions, it has proven to be difficult to isolate the principal controls on retreat. There have been many high spatial resolution studies of glacier terminus behaviour across the northwest and southeast and indeed, the entire GrIS (e.g. Moon and Joughin, 2008; Howat and Eddy, 2011; McFadden and others, 2011; Murray and others, 2015). However, while large numbers of glaciers have been analysed, no studies have included all glaciers. Furthermore, while Moon and others (2015) analysed the behaviour of a small sample of glaciers in the northwest beyond 2010, other observations of glacier retreat after this year are limited.

Glacier frontal position is controlled by a number of factors. External climatic and oceanic controls (e.g. air temperatures, ocean temperatures and sea-ice concentrations) can enhance retreat (Hanna and others, 2012a). For example, increasing air temperatures promote surface melt, leading to enhanced basal lubrication and accelerated ice velocities (e.g. Zwally and others, 2002; Hanna and others, 2008; Sole and others, 2011). Warmer ocean waters in 
contact with calving margins enhance submarine melting and terminus undercutting, thus enhancing calving and subsequent retreat (e.g. Rignot and others, 2010; Straeno and others, 2010; Seale and others, 2011; O'Leary and Christoffersen, 2013; Luckman and others, 2015; Rignot and others, 2016b; Slater and others, 2017). The presence of sea ice by contrast can inhibit retreat by suppressing calving activity at the terminus (e.g. Sohn and others, 1998; Joughin and others, 2008b; Amundsen and others, 2010; Carr and others, 2013). Alongside these external controls, large variations in outlet glacier behaviour may also result from glacier-specific factors such as fjord and bed geometry (Pfeffer, 2007; Schoof, 2007; Gudmundsson and others, 2012; Jamieson and others, 2012; Enderlin and others, 2013).

Fjord geometry can promote or inhibit retreat $\left(\mathrm{O}^{\prime} \mathrm{Neel}\right.$ and others, 2005; Carr and others, 2013, 2014). A widening fjord causes a glacier to thin; due to the principal of mass conservation, ice thickness reduces to maintain the same ice flux, subsequently weakening the terminus and promoting calving (Jamieson and others, 2012; Carr and others, 2013, 2014). A widening fjord also reduces lateral stresses between the glacier and fjord wall (Raymond, 1996). This reduces resistance to flow and leads to increasing ice velocities, once again promoting thinning and further calving. Bed geometry can also cause large variations in glacier retreat due to the processes considered by the marine ice-sheet instability hypothesis (Weertman, 1974; Schoof, 2007; Gudmundsson and others, 2012; Jamieson and others, 2012). Ice flux is strongly dependent on ice thickness at the grounding line, with increasing ice thickness leading to a higher discharge of ice across the grounding line (Gudmundsson and others, 2012). If a glacier retreats across a reverse bedrock slope, ice thickness at the grounding line will increase, leading to higher ice discharge. Thickening of the ice also increases the surface area of the terminus that is directly in contact with the ocean (Gudmundsson and others, 2012; Petlicki and others, 2015) enhancing submarine melting at the ice-ocean interface, generating a higher calving flux and accelerated ice discharge (Schoof, 2007; Gudmundsson and others, 2012). Both processes initiate a negative feedback mechanism that will only stop, theoretically, when a glacier has retreated back to a point where the terminus is no longer in a geometry that promotes retreat. These considerations highlight the potential sensitivity of outlet glaciers to changes in bed geometry and the importance therefore of understanding the variant bed topography across the northwest and southeast GrIS.

While the impacts of glacier-specific controls have been analysed in detail for a few well-mapped fjords (e.g. Porter and others, 2014; Rignot and others, 2016a), we do not have an overview or understanding of the role these internal controls play on terminus behaviour on an ice-sheet wide scale. Furthermore, while models of outlet glacier dynamics can reproduce individual glacier behaviour as observed in the field and by satellite remote sensing (e.g. Todd and Christoffersen, 2013; Chapuis and Tetzlaff, 2014; Bondzio and others, 2016; Slater and others, 2017), there are still outstanding questions when considering glacier behaviour across greater spatial scales (Goelzer and others, 2017). For example, modelling glacier behaviour requires a knowledge of bed geometry that varies considerably across the ice sheet (Morlighem and others, 2014, 2016; Rignot and others, 2016a) and we only have a detailed understanding of a few Greenlandic fjord systems (e.g. Porter and others, 2014; Carr and others, 2015; Morlighem and others, 2016; Rignot and others, 2016a). By using these limited observations to scaleup models, it is possible to wrongly assume the principal mechanisms of retreat for outlet glaciers on a regional scale. This uncertainty means that it is difficult to assess the primary controls on retreat over large spatial scales and likely limits our capacity to assess future contributions of outlet glaciers to global sea-level rise and ice-sheet mass balance.

Here, we investigate the timing and magnitude of marineterminating glacier retreat in northwest and southeast Greenland between 2000 and 2015, using remotely sensed data. We extend the spatial and temporal extent of previous work within these regions to enable a high-resolution analysis of annual frontal position change of all outlet glaciers. We then analyse the impact of fjord and bed geometry on outlet glacier behaviour.

\section{DATA AND METHODS}

We examined 276 marine-terminating outlet glaciers in the northwest (100) and southeast (176) regions of the ice sheet, at an annual resolution between 2000 and 2015 (Fig. 1). To maintain a high temporal resolution, glaciers were excluded from the analysis if terminus position data were not available for more than 2 consecutive years. This excluded 20 glaciers, $7 \%$ of the total dataset and likely has a limited impact on results. After removing these glaciers, we included all outlet glaciers regardless of terminus width, with the exception of two surge-type glaciers (Harald Moltke Brae and Courtaulds Glacier) as these can undergo dynamic changes independent of forcing factors (Murray and others, 2015). We analysed individual glacier retreat rates to assess intra-regional variability. We also categorised the glaciers based on bed geometry and fjord planform geometry to determine broad relationships between different common glacier properties and observed retreat behaviour.

\subsection{Glacier frontal position}

We obtained Landsat 4-5 TM, 7 ETM+ and 8 satellite imagery from the USGS Global Visualisation Viewer (http:// glovis.usgs.gov/) and the USGS Earth Explorer (http://earthexplorer.usgs.gov/). Images were acquired annually at $30 \mathrm{~m}$ resolution (visible bands 1,2 and 3), and as close to 31 July as possible. While this may be considered early for a minimum terminus position, this date was also selected based on the image availability criteria; later in the melt season, there was greater cloud cover meaning that more glaciers would have been excluded, thereby decreasing the impact of our results.

Terminus positions were digitised from sequential satellite images, using a fixed-width reference box oriented approximately parallel to ice flow, and joined with an arbitrary reference line up-glacier (e.g. Moon and Joughin, 2008; Carr and others, 2013). Change in frontal position was calculated by dividing the change in area of the reference box by the width, giving a relative change in annual frontal position and overall mean retreat. This method therefore accounts for the irregularity in the shape of calving margins (Moon and Joughin, 2008). The largest potential source of error results from manual digitisation of terminus positions and was estimated by repeatedly digitizing sections of rock coastline in both study regions (following Carr and others (2014)), 

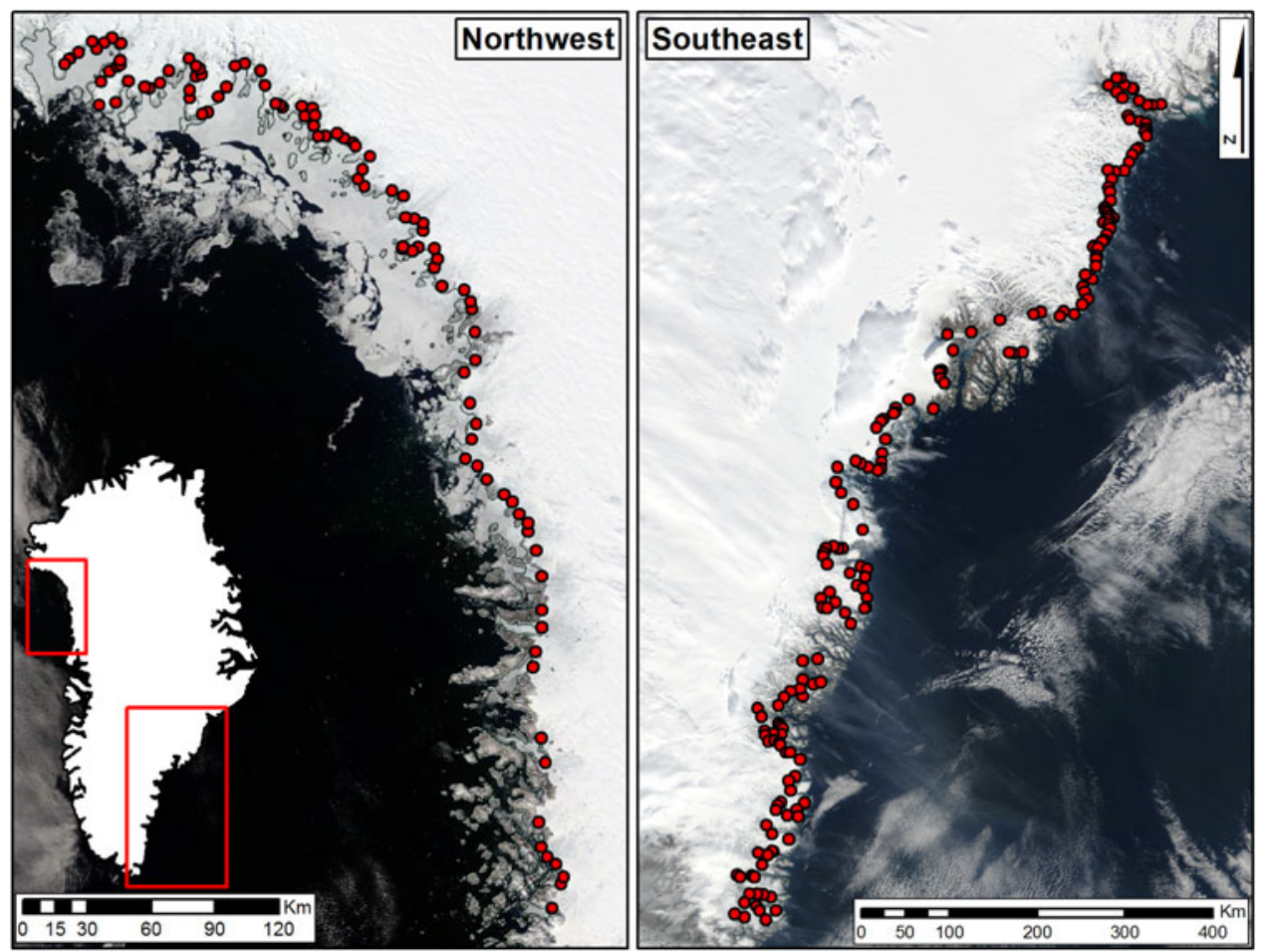

Fig. 1. Overview map of the northwest and southeast study areas. Base images are MODIS (Terra) corrected reflectance images available from EOSDIS NASA Worldview (https://worldview.earthdata.nasa.gov/).

producing errors of $\pm 9.4 \mathrm{~m}$ for the northwest and $\pm 15.3 \mathrm{~m}$ for the southeast.

To manage the large dataset and to represent and discuss results, we selected the following categories of retreat rates for glaciers within both regions, based on the overall mean retreat rates that each glacier experiences for the 15-year time period: $>-200,-200$ to $-100,-100$ to $-50,-50$ to $-15,-15$ to $0 \mathrm{~m} \mathrm{a}^{-1}$ and an advancing category of $0-20$ $\mathrm{m} \mathrm{a}^{-1}$. We analyse the categories within the generated error values with caution and therefore consider glaciers within these margins as exhibiting 'no discernible change' (i.e. the 0 to -15 and 0 to $20 \mathrm{~m} \mathrm{a}^{-1}$ categories). These categories were selected to ensure that there were over ten glaciers in each category, with the single exception of the advancing category in the northwest as only one glacier advanced in this region during our study period.

\subsection{Fjord geometry}

We carried out a qualitative assessment of fjord geometry for all glaciers in the study, following the classification of fjord shape by Carr and others (2014) (Fig. 2). We characterised the planform geometry of the fjord, as exhibited between the most advanced and most retreated glacier front position

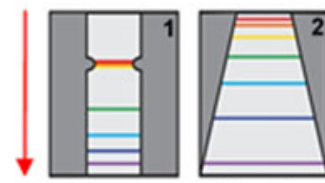

Glacier retreat direction
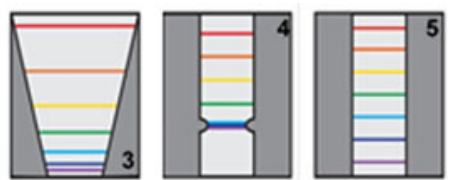

Fig. 2. Illustration of categories used for the analysis of fjord geometry. Geometries include (1) retreat from a lateral pinning point; (2) retreat into a widening fjord; (3) retreat into a narrowing fjord; (4) retreat onto a lateral pinning point and (5) parallel retreat. during our 15-year period of observation, to isolate the influence of fjord geometry over the length of the fjord that the glacier occupied during the study period. We use this method to gain an understanding of the broad patterns of fjord geometry for glaciers in the northwest and southeast region and therefore record the dominating geometry for each glacier and its potential impact on retreat behaviour. Categories of fjord geometry included the presence of lateral pinning points, widening and narrowing fjords and minimal change in fjord width (Fig. 2). While this approach is simple, it allows for the categorisation of fjord geometry for a large sample of glaciers without needing to account for the additional complexity of asynchronous terminus retreat. This method was also used effectively to characterise fjord morphology for a large sample size of glaciers in Novaya Zemlya (see Carr and others, 2014).

\subsection{Bed geometry}

Bed geometry data were acquired from the IceBridge BedMachine (v2) dataset, which is derived from ice velocities at $400 \mathrm{~m}$ spatial resolution and are available from https:// nsidc.org/data/IDBMG4/versions/2 (Morlighem and others, 2014). We tested the difference between Version 2 of IceBridge BedMachine and the recently released Version 3 (Morlighem and others, 2017) and found that for 20 glaciers from each region representing a range of retreat characteristics, there was no difference in geometric interpretation using either Version 2 or 3. Bed geometry was then analysed by producing an elevation profile of topography underlying the centreline of each outlet glacier. Centreline elevation profiles were generated between the 2007 and 2015 terminus positions, which cover the years when the IceBridge BedMachine (v2) data are available. The dominating geometry for each glacier was categorised as either a (1) reverse 
bedrock slope (bedrock sloping downwards, up-glacier away from the grounding line) or (2) normal bedrock slope (bedrock sloping upwards, up-glacier away from the grounding line) (Figs. 2 and 3). While we recognise that a centreline profile excludes lateral across-fjord variations that could influence retreat rates, our aim is to provide a general overview of the geometry experienced by each glacier. Although we found small-scale lateral variations in bed depth at some glaciers, the general shape of the bed along flow did not change considerably. Furthermore, the spatial resolution of the BedMachine (v2) dataset is unlikely to resolve small-scale features such as topographic pinning points or sills, and while we recognise the importance of these features in determining frontal position, we do not include these in our analysis of bed geometry. Furthermore, recent studies of well-mapped fjords (e.g. Rignot and others, 2016a) indicate that bed geometry varies by considerably more than current bathymetric maps show; it is therefore important that we continue these detailed surveys (particularly near glacier fronts) to observe the small spatial scale variations, as these likely have considerable impact on frontal position change.

\subsection{Statistical analysis}

We carried out statistical tests to analyse whether the observed spatial and temporal variations in retreat rates were significant. To initially assess whether glacier retreat was different between the northwest and southeast, we used a Kruskal-Wallis test to analyse the statistical difference in overall mean retreat rate (2000-2015) between each region. The Kruskal-Wallis test returns a $p$-value for the null hypothesis that two or more samples within the data come from the same population. This test is a non-parametric version of the one-way analysis of variance test and does not assume normal distribution within the data. This is the case for glacier retreat rates in our study, and was determined using the Kolmogorov-Smirnov test, to test for the normal distribution. Following convention, a significance level of 0.05 is used. This means that a $p$-value of $\leq 0.05$ indicates that it is unlikely that the samples come from the same population, and in the case of our results, retreat rates of outlet glaciers in the northwest and southeast would be significantly different. This method of statistical analysis has been used effectively in a range of other studies of outlet glacier retreat behaviour (e.g. Miles and others, 2013; Carr and others, 2014; Carr and others, 2017).

We then used a changepoint detection method (Killick and others, 2012, 2016; Killick and Eckley, 2014) to further analyse time series of individual glacier retreat rates. This method allowed for the objective determination of distinct periods of retreat rate behaviour exhibited by individual glaciers, which were then used to investigate intra-regional patterns of temporal variability. To determine if or when glaciers advanced and retreated, we need to determine when they have shifted from one mode to another. In order to automatically determine when this occurs, we use changepoint analysis (see Eckley and others (2011) for an introduction). Formally, a changepoint is a point in time where the statistical properties of prior data are different from the statistical properties of subsequent data; the data between two changepoints are a segment. There are various ways that one can determine when a changepoint should occur, but the best fit for our data is to consider changes in both the mean and time trend of our estimates. To automate this, we use the cpt.reg function in the $\mathrm{R}$ changepoint package available from CRAN (Killick and Eckley, 2014). This function uses the PELT algorithm (Killick and others, 2012) for fast and exact detection of multiple changes in a time series. The function returns changepoint locations and estimates of the mean, time trend and variance between changes. We use the default MBIC penalty value (Zhang and Siegmund, 2007) with a minimum segment length of 4 . For given data $y_{1} \ldots y_{n}$ the PELT algorithm balances the trade-off between fit and complexity through optimizing

$$
\sum_{i=1}^{m+1}\left[\mathcal{C}\left(y_{\left(\tau_{i-1}+1\right): \tau_{i}}\right)\right]+\beta f(m)
$$

over $m$ (number of changepoints), $\tau_{i=1: m}$ (the changepoint locations) and the parameters within the cost function $\mathcal{C}$. Following convention, $\tau_{0}=0$ and $\tau_{m+1}=n$. The cost function we use is the likelihood of the model $y_{t}=\alpha+\beta t+\varepsilon$ where $\varepsilon \sim N\left(0, \sigma^{2}\right)$, thus we have parameters $\alpha, \beta$ and $\sigma$ for each segment. The cost function is optimised using maximum likelihood estimates of the parameters.

We also conducted a preliminary linear regression analysis to investigate potential causal links between glacier front position and annual records of air temperature (obtained from Danish Meteorological Stations, available from http://www.dmi.dk/en/vejr/), ocean temperature (acquired from TOPAZ data, available from http://topaz. nersc.no) and sea-ice concentration (extracted from US National Ice Centre charts, available from http://www. natice.noaa.gov/). Our results however showed no statistically significant correlations between these controls and the timing or magnitude of glacier retreat in either study region. The spatial and temporal coverage of these data meant however that their limitations prevented a more indepth analysis, as has been adopted by previous observational and modelling studies that have, at least in part, attributed retreat to the impact of climate and ocean (e.g. Howat and others, 2008b; Moon and Joughin, 2008; Straneo and others, 2012; Hanna and others, 2013). We therefore chose not to include any analysis of climate and oceanic data within this study.

After the qualitative analysis of fjord and bed geometry, we carried out a Wilcoxon test (Miles and others, 2013) to investigate whether retreat rates were significantly different between glaciers situated on reverse and normal bedrock slopes. The Wilcoxon test is a non-parametric version of a paired $t$-test and does not assume normal distribution of the data. This is required as glacier retreat rates within our study are not normally distributed. The test is used to determine whether samples from the same population are significantly different that would be indicated by a $p$-value of $>0.05$. In the case of our study, this would indicate

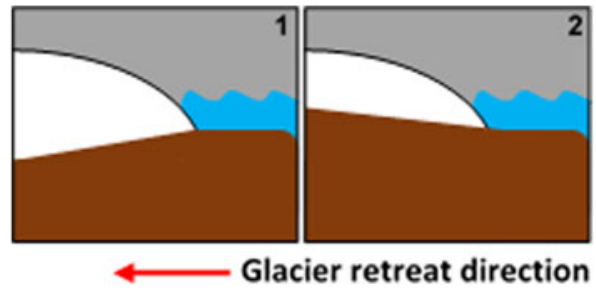

Fig. 3. Illustration of the categories used for the analysis of bed geometry: (1) reverse bedrock slope and (2) normal bedrock slope. 
whether glaciers with different bed geometries had significantly different retreat rates.

\section{RESULTS}

\subsection{Spatial and temporal patterns of glacier retreat}

Our results showed that in northwest Greenland, 99\% of glaciers retreated and 1\% advanced between 2000 and 2015; in the southeast, 96\% retreated and 4\% advanced (Fig. 4). Results from the Kruskal-Wallis test indicated that retreat rates were significantly different between the two regions $(p=<0.01)$. Mean regional annual retreat rates were higher in the northwest $\left(-90 \mathrm{~m} \mathrm{a}^{-1}, \mathrm{SD}=110 \mathrm{~m}\right)$ compared with the southeast $\left(-70 \mathrm{~m} \mathrm{a}^{-1}, \mathrm{SD}=190 \mathrm{~m}\right)$, and this was also reflected in the proportion of glaciers that experienced retreat rates of $>-200 \mathrm{~m} \mathrm{a}^{-1}(13 \%$ in the northwest and $7 \%$ in the southeast) (Fig. 4). Although when averaged, glaciers in the northwest retreated persistently throughout the study period, retreat rates were substantially higher during 2001-2004 and 2010-2013 (when mean retreat rates were $\left.-100 \mathrm{~m} \mathrm{a}^{-1}\right)$, and reached their maximum in $2015(-140$ $\mathrm{m} \mathrm{a}^{-1}$ ) (Fig. 5). The lowest retreat rates were recorded in 2014, when retreat rates were within the margins of 'no discernible change'. In the southeast, retreat was not sustained over the entire study period (Fig. 5). Retreat rates were an order of magnitude greater during 2001-2004 (mean = $\left.-98 \mathrm{~m} \mathrm{a}^{-1}\right)$, compared with 2005-2009 $\left(-10 \mathrm{~m} \mathrm{a}^{-1} / \mathrm{no}\right.$ discernible change) (Fig. 5). After 2009, mean regional annual retreat rates showed much larger inter-annual variations: in 2010, 2013 and 2015 retreat rates reached between -80 and $>-200 \mathrm{~m} \mathrm{a}^{-1}$, whereas in 2011, 2012 and 2014, there was net annual advance in glacier frontal position (Fig. 5).

The timing and pattern of retreat also varied within the two regions (Figs 4,5 ). There were no consistent spatial patterns in terms of glaciers within the same region retreating at similar rates (Fig. 4). For example, the one advancing glacier in the northwest (NW34) (Fig. 4) was surrounded by glaciers with retreat rates between -15 and $>-200 \mathrm{ma}^{-1}$ (Fig. 4). This variability in retreat rate for neighbouring glaciers was also observed in the southeast (Fig. 4). For example, while the mean retreat rate of Kangerdlugssuaq was $>-200 \mathrm{ma}^{-1}$, other glaciers within the same fjord system retreated at lower rates (ranging between -15 and $-200 \mathrm{~m} \mathrm{a}^{-1}$ ) or even experienced no discernible change. This intra-regional variability in retreat rates is also apparent in the timing of retreat with many glaciers not following the mean trends in regional retreat rate (Fig. 5).

Due to the variable timing and magnitude of frontal position change we observed in our results, we used changepoint analysis to determine whether changes in glacier retreat rates occurred at similar times, both within and between our study regions. Changepoints were detected for 60 glaciers in the northwest (60\% of total) and 102 glaciers in the southeast (58\% of total). In the northwest, $50 \%$ of the changepoints (30 glaciers) were detected in either 2004 or 2009. The majority of the 2004 changepoints marked a reduction in retreat rates, compared with previous years, while retreat rates generally increased after 2009 (Fig. 6). In the southeast, $68 \%$ of the changepoints (69 glaciers) were detected in either 2004 or 2010 (Fig. 6). In both of these

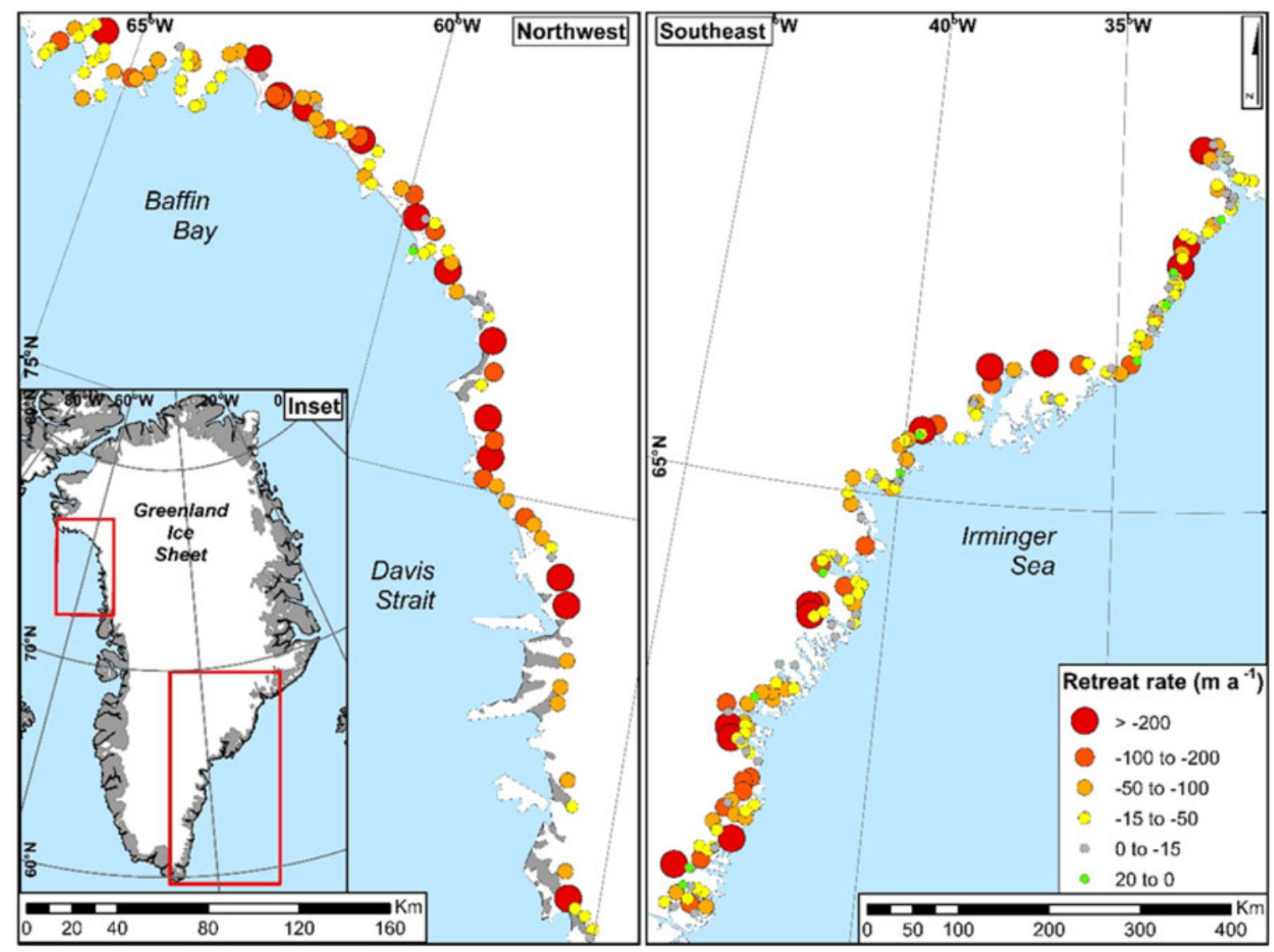

Fig. 4. Mean annual retreat rates of outlet glaciers in the northwest and southeast. Size and colour of circles represent mean annual retreat rate of each glacier for the period 2000-2015. 

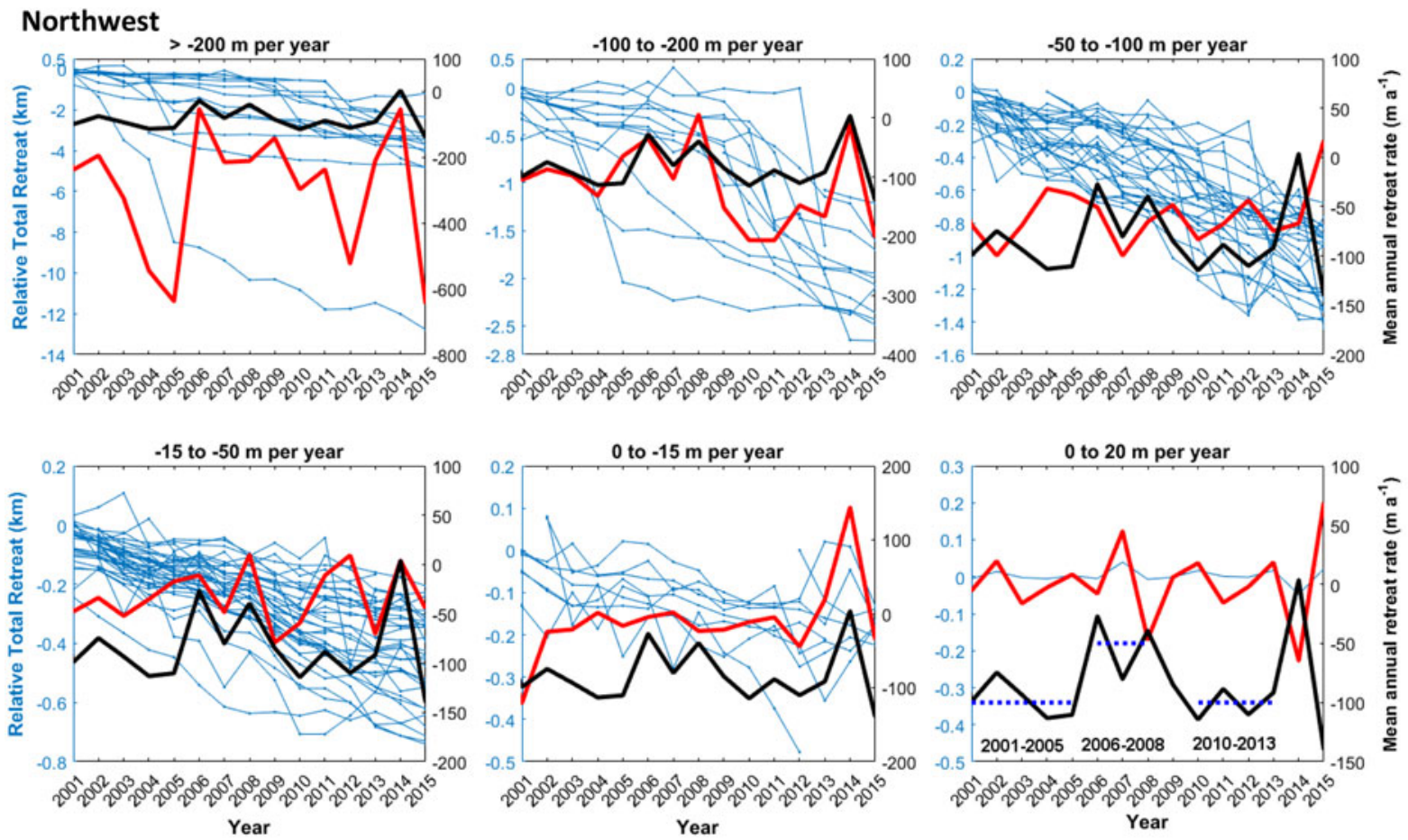

\section{Southeast}
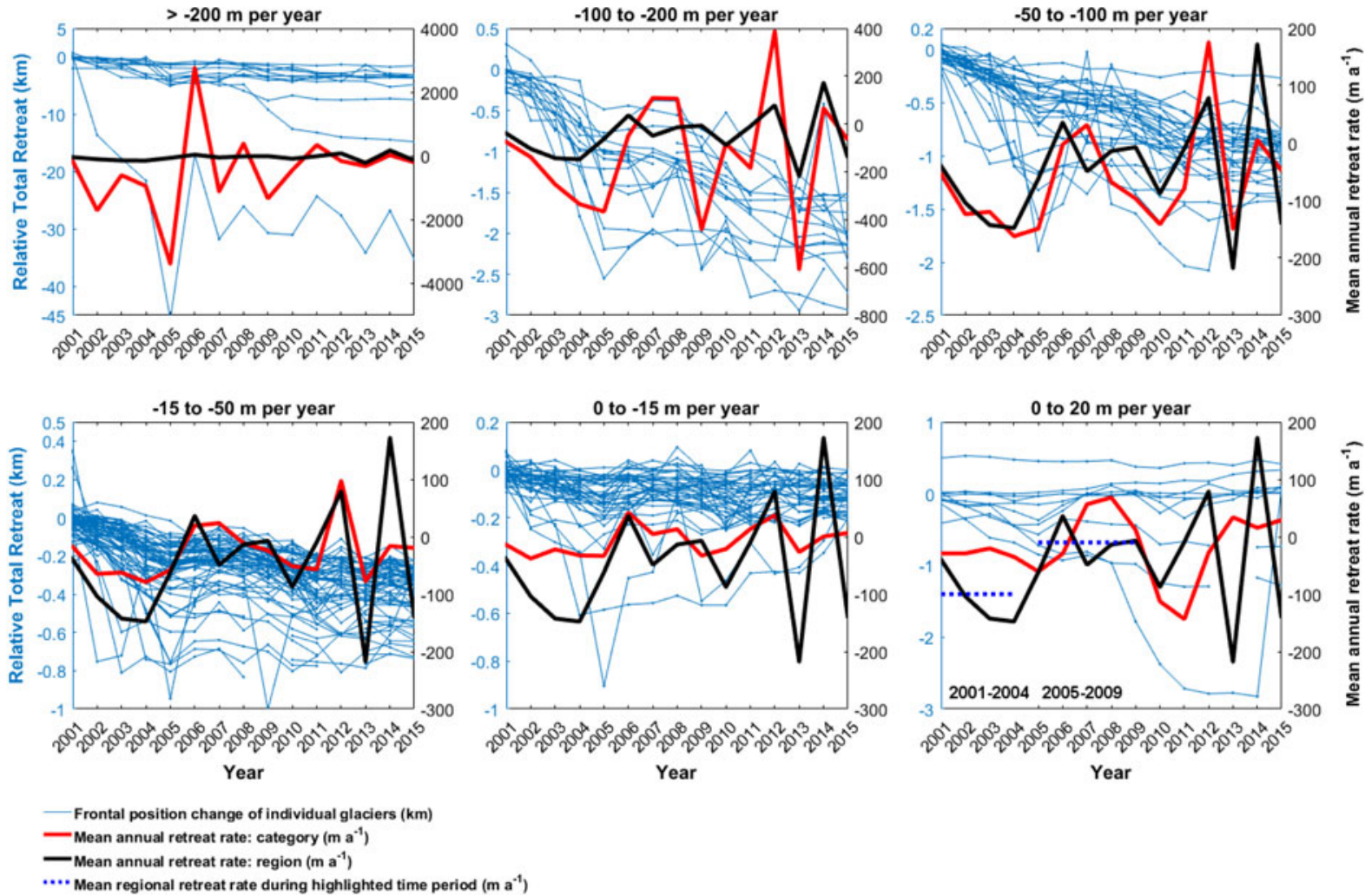

Fig. 5. Temporal patterns of outlet glacier retreat in the northwest and southeast between 2000 and 2015. Left axis: relative total retreat ( $\mathrm{km}$ ) for all glaciers included in the study (blue lines). Right axis: mean annual retreat rate $\left(\mathrm{m} \mathrm{a}^{-1}\right)$ for the glaciers within each category/plot (red line). Each plot also shows mean annual retreat rate $\left(\mathrm{m} \mathrm{a}^{-1}\right)$ of the entire region (right axis, black line). Note the different vertical scales in each plot to account for the differing mean annual retreat rates in each region. Figure also shows mean regional retreat rate for specific time periods: 2001-2005, 2006-2008 and 2010-2013 in the northwest, and 2001-2004 and 2005-2009 in the southeast (right axis, blue dotted lines) to demonstrate considerable differences in retreat rates between this time periods.

years, the majority of changepoints indicated lower retreat rates than in previous years, although this pattern was not as pronounced as in the northwest (Fig. 6). Twelve of the glaciers in the southeast had two changepoints. In all but two instances, the first changepoint was detected in 2004 and indicated enhanced retreat after 2004, while the second changepoint was detected in 2010, and indicated a switch from retreat to advance from 2010 onwards (Fig. 6). There were no glaciers in the northwest for which multiple changepoints were detected. These results show that glaciers that 

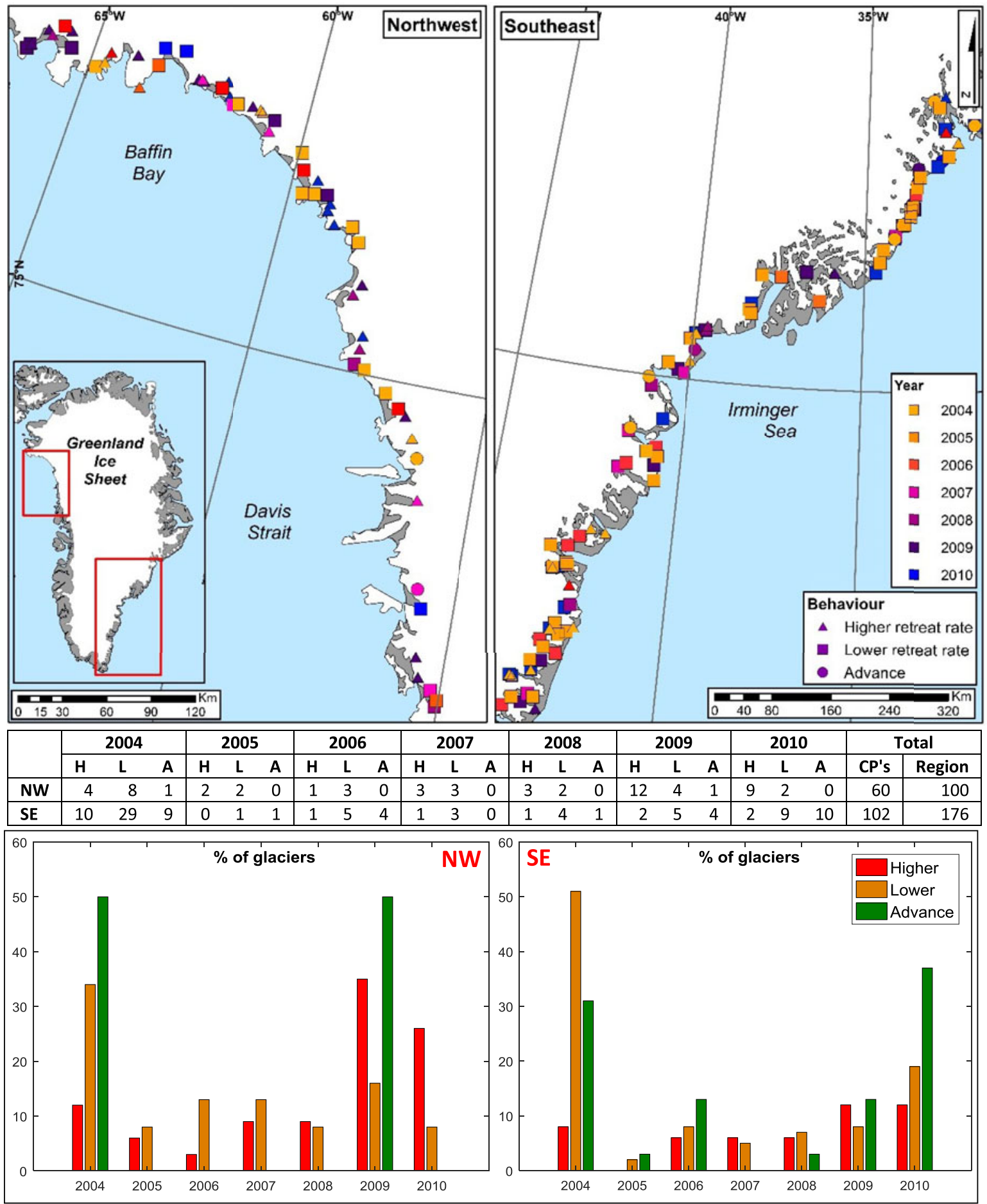

Fig. 6. Changepoints detected between 2000 and 2015 for glaciers in the northwest and southeast. Top panels show maps of the spatial distribution of changepoints. Symbols indicate the type of changepoint (e.g. higher retreat rate, lower retreat rate or advance after the changepoint year). Colour indicates the year in which the changepoint was detected. The table displays the number of changepoints for each region, the type of these changepoints and the year in which they were detected. The table also indicates the total number of changepoints detected for each region and the total number of glaciers. Note that 12 of the glaciers in the southeast had two changepoints: one in 2004 and one in 2010. The histogram panels show these numbers as a percentage of the type of changepoints that were detected for each year.

experienced a changepoint changed at common times (2004 and 2009 in the northwest and 2004 and 2010 in the southeast). However, many glaciers in both regions (60 glaciers in the northwest and 108 in the southeast) did not experience a changepoint in these years. Consequently, there was no common timing of change for the entire population of study glaciers (Fig. 6).

\subsection{Fjord and bed geometry}

Our results showed that while almost all glaciers retreated (99\% in the northwest and $96 \%$ in the southeast), regardless of glacier-specific characteristics, there was also evidence of geometric control on retreat patterns. In both regions, a high percentage of glaciers that retreated $>200 \mathrm{~m} \mathrm{a}^{-1}(90 \%$ in the northwest; $84 \%$ in the southeast) and between 100 and 
$200 \mathrm{~m} \mathrm{a}^{-1}(78 \%$ in the northwest; $59 \%$ in the southeast) retreated from lateral pinning points or into widening fjords. (Fig. 7). The majority of glaciers with lower retreat rates were located in narrowing fjords or those with minimal geometric change; the percentage of glaciers experiencing these fjord geometries increased as retreat rate decreased in both the northwest and the southeast (Fig. 7).

Our results also show that variations in retreat rates were associated with different centreline bed slopes (Fig. 8). The percentage of glaciers situated on reverse bedrock slopes increased with increasing retreat rates in both the northwest and the southeast (Fig. 8). In both regions, no advancing glaciers were situated on reverse bedrock slopes, whereas glaciers that retreated $>200 \mathrm{~m} \mathrm{a}^{-1}$ had the highest percentage associated with reverse slopes $(50 \%$ in the northwest and $40 \%$ in the southeast) (Fig. 8). The exception to this is the -15 to $-50 \mathrm{~m} \mathrm{a}^{-1}$ category in the northwest, which had a much higher percentage of glaciers on reverse slopes compared with those with higher retreat rates. It must be noted that here the higher percentage is due to a smaller sample size of glaciers for this category, compared with those in the subsequent two categories in the northwest (Fig. 8). The Wilcoxon test, which we used to assess the statistical significance of the retreat rates of glaciers with different bed geometries, suggested there was a significant difference between the retreat rates of glaciers retreating across a normal slope compared with those that retreated across a reverse bedrock slope ( $p$-value $=<0.05$ in the northwest and $<0.01$ in the southeast). Glaciers situated on reverse bedrock slopes therefore experienced higher retreat rates.

\section{DISCUSSION}

Our study demonstrates a near-ubiquitous retreat of marineterminating outlet glaciers in the northwest and southeast Greenland between 2000 and 2015 (Figs 4, 5). However, frontal position change varied spatially and temporally both within and between these regions. These findings are consistent with many studies which report on both the retreat and complex behaviour of outlet glaciers across Greenland (e.g.
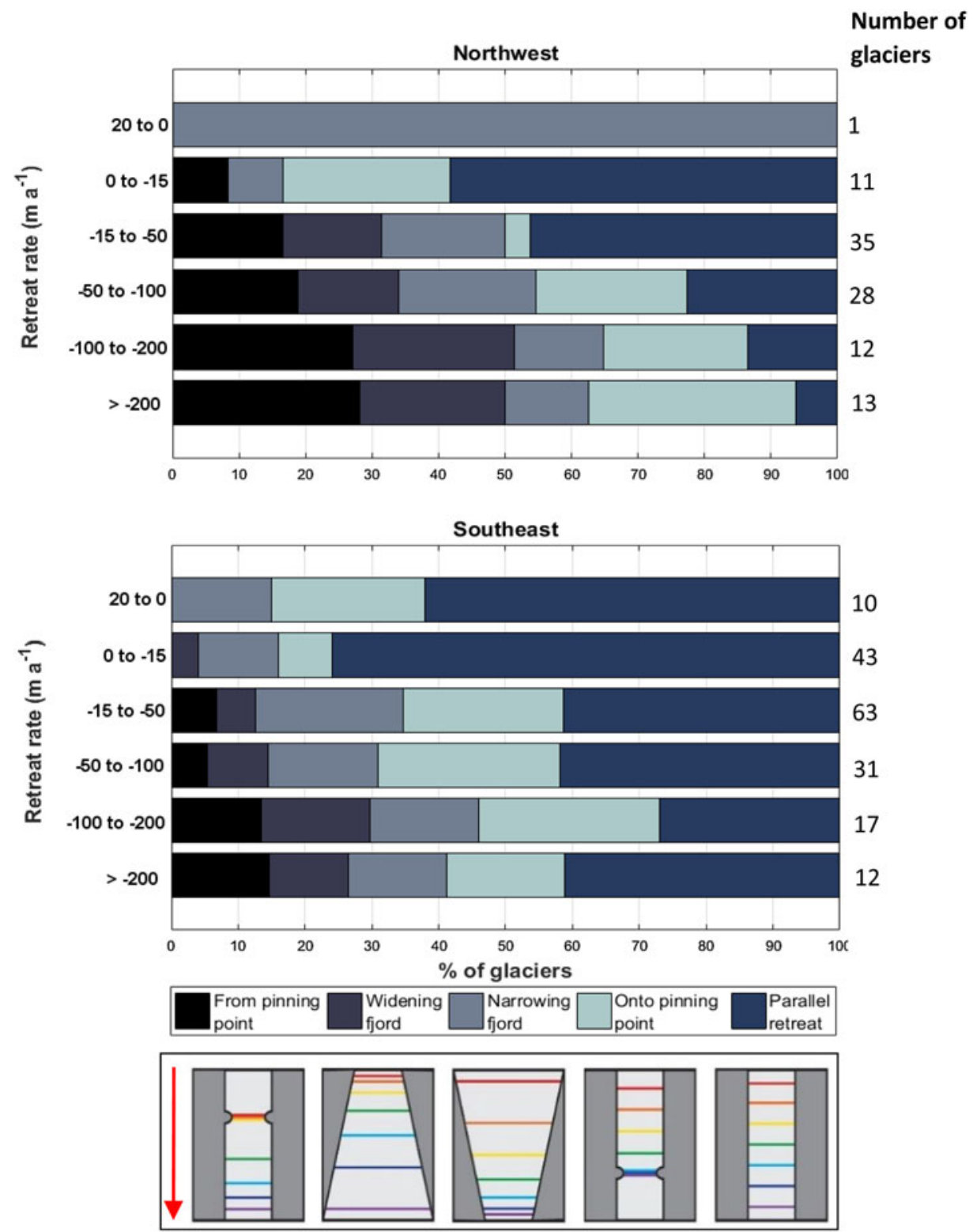

Fig. 7. Observed fjord plan geometry for glaciers exhibiting different retreat rates in the northwest and southeast. Stacked horizontal bars indicate percentages of glaciers within the specified retreat rate categories. Colours indicate fjord geometries specified in the key. The total number of glaciers within each category is provided in the right-hand column. 

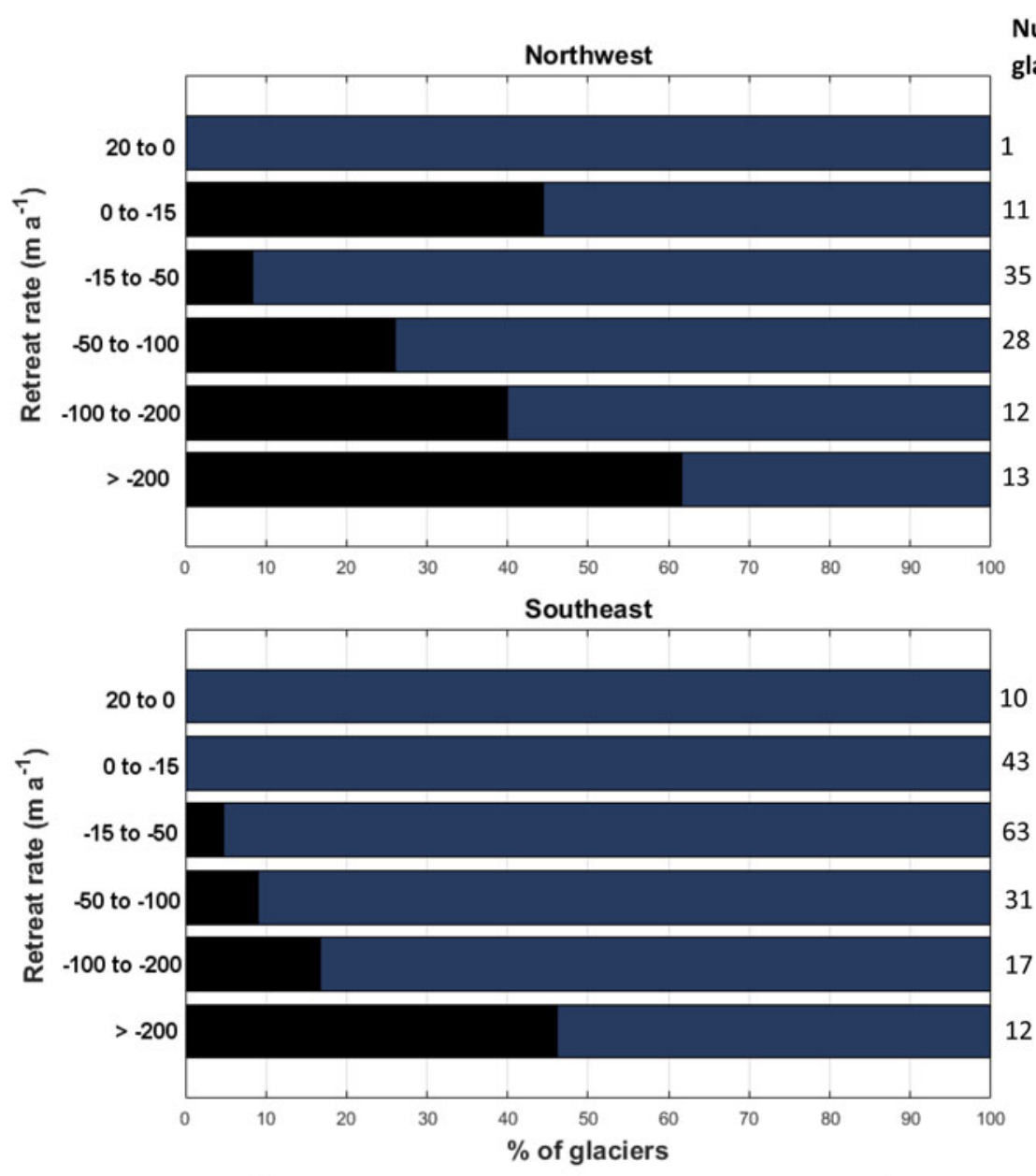

Reverse bedrock slope $\square$ Normal bedrock slope

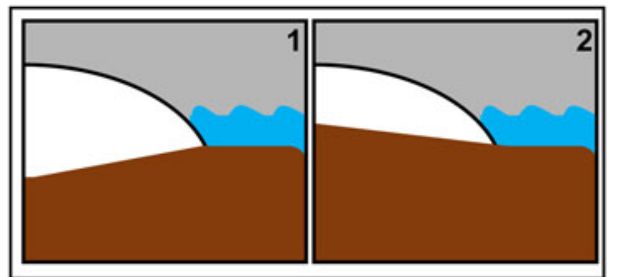

Fig. 8. Observed bed geometries for glaciers at certain retreat rates for the northwest and southeast. Stacked horizontal bars indicate percentages of glaciers within the specified retreat rate categories. Colours indicate bed geometries specified in the key. The total number of glaciers within each category is provided in the right-hand column.

Moon and Joughin, 2008; Howat and Eddy, 2011; McFadden and others, 2011; Carr and others, 2013; Murray and others, 2015).

\subsection{Retreat in the northwest}

Retreat in the northwest was sustained during 2000-2015 (Fig. 5). However, two periods of retreat were substantially faster (-98 $\mathrm{ma}^{-1}$ during 2001-2004 and $-101 \mathrm{ma}^{-1}$ during 2010-2013) than the regional mean rates across the entire study period (Fig 5). These two periods of rapid retreat were separated by a period of much slower mean regional retreat (-48 $\mathrm{m} \mathrm{a}^{-1}$, during 2005-2009), consistent with the results from other studies within the region (Moon and Joughin, 2008; McFadden and others, 2011; Carr and others, 2013; Murray and others, 2015). This period of slower retreat was also highlighted by our changepoint analysis, which showed that for glaciers with changepoints $(60$ glaciers), 50\% (30 glaciers) showed a reduction in retreat

Number of glaciers

11 35 8 63 1 7 2 
highlighted by our changepoint analysis; for glaciers that showed changepoints indicating a shift to higher retreat rates, $61 \%$ were detected in either 2009 or 2010 (Fig. 6) demonstrating an acceleration in retreat rate after these years. These observations of accelerated retreat rates after 2010 correlate with increased ice velocities from observations of a sub-sample of 16 glaciers in the northwest region after 2010 (Moon and others, 2015).

\subsection{Retreat in the southeast}

Between 2000 and 2010, retreat in the southeast followed a similar pattern to the northwest (Fig. 5). A period of rapid retreat, during 2001-2004 $\left(-98 \mathrm{~m} \mathrm{a}^{-1}\right)$, was followed by retreat rates an order of magnitude slower during 2005$2009\left(-10 \mathrm{~m} \mathrm{a}^{-1}\right)$ (Fig. 5). This behaviour was also detected by the changepoint analysis: changepoints were detected for 108 glaciers and $68 \%$ of these glaciers showed a reduction in retreat rate after 2004 (Fig. 6). These results are consistent with other studies in the southeast that detect rapid retreat before 2005, followed by a considerable slowdown (e.g. Rignot and others, 2004; Howat and others, 2008a, b; Joughin and others, 2008a; Moon and Joughin, 2008; Howat and Eddy, 2011). Our most recent observations since 2010 reveal large inter-annual variations with mean regional frontal positions alternating between net annual retreat and advance (Fig. 5). Mean annual retreat rates in 2013 and 2015 exceeded those during 2001-2004, while in 2012 and 2014, there was net advance (Fig. 5). As a result, the overall mean retreat rate for 2010-2015 was $-40 \mathrm{~m} \mathrm{a}^{-1}$, compared with $-98 \mathrm{~m} \mathrm{a}^{-1}$ during 2001-2004 and $-10 \mathrm{~m} \mathrm{a}^{-1}$ during 2005-2009. This demonstrates that while mean retreat rates have accelerated since 2010, recent frontal change has been characterised by much greater variability than over the previous decade and in comparison to the northwest. The changepoint analysis reflects these observations; $38 \%$ of the glaciers that switched from retreat to advance switched in 2010 but a high percentage of glaciers also switched to lower retreat rates after 2010. Ongoing monitoring of frontal position change will be necessary to place the recent patterns of dynamic change into a longer term context and to determine what factors are responsible for driving this variability.

\subsection{Influence of fjord and bed geometry}

The overall broad patterns of retreat that have occurred over the 15-year observational period suggest that wider climatic and oceanic controls are exerting some level of influence on outlet glacier behaviour. However, the complex spatial variability in both the timing and magnitude of glacier retreat between and within each region (Fig. 4), including neighbouring glaciers experiencing contrasting behaviour, implies that frontal position is at least partly controlled by local variation in glacier-specific factors, such as fjord and bed geometry.

Our results showed that higher retreat rates were associated with glaciers retreating into widening fjords and/or from lateral pinning points, while lower retreat rates were associated with fjords that were either narrowing or showed minimal variation in width (Fig. 7). These findings support a previous work in Greenland (Warren and Glasser, 1992) and more recently from Novaya Zemlya (Carr and others, 2014) where years of rapid retreat corresponded to sections of widening fjord and retreat from lateral pinning points, demonstrating that fjord geometry exerts a major influence on outlet glacier retreat. At Midgaard Glacier in the southeast (Sermilik Fjord), retreat occurs during 2007-2013 and this also corresponds to the glacier retreating into a wider section of the fjord. This is followed by minimal change in frontal position in the last two years of the study period, when the fjord narrows considerably. This behaviour is also observed at Alison Glacier in the northwest, where retreat during 2001-2005 correlated with a widening fjord. This period of rapid frontal position change is followed by lower and more consistent retreat rates after 2005, coincident with a lateral pinning point in the fjord. This matches the earlier relationship with fjord geometry during 1976-2001, when progressive but consistent retreat was observed alongside minimal variation in fjord width, followed by rapid retreat into a widening fjord during 2001-2004 (Carr and others, 2013).

The importance of topographic control on retreat rates is manifest in the bed shape as well as the fjord planform geometry with higher retreat rates associated with reverse bedrock slopes, and lower retreat rates associated with normal bedrock slopes (Fig. 8), findings consistent with the previous work in well-mapped fjords (e.g. Rignot and others, 2016b). We observed rapid retreat at a number of glaciers, which far exceeded rates on neighbouring glaciers, which we attribute to variation in bed geometry. For example, the only glacier that experienced net advance (during 2000-2015) in the northwest (NW34) is situated on a normal bedrock slope, while nearby Kong Oscar (just $20 \mathrm{~km}$ north, with a retreat rate of $>-200 \mathrm{~m} \mathrm{a}^{-1}$ ) is situated on a reverse bedrock slope. Further north, NW92 also retreated at a mean annual rate of $>-200 \mathrm{~m} \mathrm{a}^{-1}$ across a reverse bedrock slope, while the adjacent three glaciers north and five glaciers south of NW92, all located on normal bedrock slopes, retreated at the rates of -15 to $-50 \mathrm{~m} \mathrm{a}^{-1}$. The close spatial proximity of these glaciers would appear to exclude the effect of climatic and oceanic controls on changes in frontal position, thereby suggesting bed geometry as a major control on retreat rate. Despite their close spatial proximity in the same fjord system, Tracy and Heilprin Glaciers experience considerably different patterns of retreat that are attributed to differences in bed depth (Porter and others, 2014). Asynchronous terminus retreat at Humboldt Glacier, northwest Greenland, has also been linked to differences in bed geometry between the northern and southern sections of the terminus (Carr and others, 2015). These differences in geometry at Tracy and Heilprin and also at Humboldt may be acting as a catalyst, allowing other processes to enhance calving and retreat. For example, the deeper grounding line at Tracy Glacier allowed access for warmer waters to reach the terminus, enhancing submarine melt leading to three times as much retreat than at Heilprin (Porter and others, 2014).

This contrasting behaviour can also be observed in the southeast, where three neighbouring glaciers in close proximity $(<20 \mathrm{~km})$ in 2000 have retreated at considerably different rates. SE78 experienced net advance during the study period, SE77 experienced low mean annual retreat $(-15$ to $-50 \mathrm{~m} \mathrm{a}^{-1}$ ), while SE76 retreated at a substantially higher rate $\left(>-200 \mathrm{~m} \mathrm{a}^{-1}\right)$. All three glaciers are situated in fjords with little to no fjord width variation but considerable variation in bed geometry, with the SE76 (retreating at much higher rates) situated on a reverse bedrock slope, while the two that experienced little frontal position change situated on normal bedrock slopes. 
Our detailed results in combination with the work of others (e.g. Porter and others, 2014, Carr and others, 2015; Rignot and others, 2016b) therefore confirm that localised glacier behaviour, as evidenced by changes in terminus position, can vary considerably as a result of varying fjord and bed topography. It is therefore clear that as glaciers experience different fjord geometry as they retreat, their behaviour may change with enhanced retreat as a fjord widens and/or deepens and suppressed retreat with a narrowing and/or shallowing fjord, even where the glacier is subjected to the same climatic forcing. Detailed studies of glacier-specific conditions including accurate bathymetric data are therefore essential to inform ice-sheet models, particularly models of submarine melt, and enable them to better predict and quantify future patterns of frontal position change, and thus ice loss.

\section{CONCLUSIONS}

We present a 15-year record of annual frontal position change for 276 outlet glaciers in the northwest and southeast GrIS. Outlet glacier retreat is near-ubiquitous during 20002015. There is however considerable inter-annual variability in the timing and magnitude of ice front retreat both within and between the regions. Both regions experienced sustained and rapid retreat $\left(\sim-100 \mathrm{~m} \mathrm{a}^{-1}\right)$ during 2001-2004 followed by a subsequent slowdown. In the northwest, following slowdown, mean retreat rates for the period 2010-2015 were the highest for the whole period of observation confirming substantial recent acceleration. In the southeast by contrast, retreat patterns during 2010-2015 were characterised by considerable inter-annual variability, hence while retreat during 2015 was the highest of any year $\left(>-200 \mathrm{~m} \mathrm{a}^{-1}\right)$, the mean retreat rate $\left(-40 \mathrm{~m} \mathrm{a}^{-1}\right)$ was less than half that observed during 2001-2004. While the near-ubiquitous retreat observed implies a broad climatic and/or oceanic driver, our work also suggests that the asynchronous patterns of annual frontal position change are, at least in part, controlled by the fjord and bed geometry. Differences in the timing and magnitude of local retreat reflects variation in glacier-specific factors and demonstrates the potential of these characteristics to modulate glacier behaviour and contribute considerably to the patterns of ice loss. Given the importance of fjord and bed geometry in modulating patterns of retreat, it is clear that there is an ongoing need for improved observations of bed geometry. Without detailed bathymetry of fjord systems and glacier trunk beds, particularly close to the ice fronts of outlet glaciers, it will not be possible to constrain and quantify accurately the impact of small-scale topographic features that are known to have considerable influence on frontal position change.

\section{ACKNOWLEDGEMENTS}

This work was supported by an M.Phil. research scholarship awarded to C. Bunce by the School of Geography, Politics and Sociology at Newcastle University and a Ph.D. studentship awarded to $C$. Bunce through the $E^{3}$ Natural Environmental Research Council Doctoral Training Partnership (NE/L002558/1). We acknowledge the availability of several datasets used within the study. A variety of Landsat 4+5, 7 and 8 satellite images were obtained from the USGS Earth Explorer and GLOVIS platforms. Version 2 of the IceBridge BedMachine dataset was acquired from the National Snow and Ice Data Center (as produced by
Morlighem and others (2015)). Atmospheric and oceanic data were also acquired from several sources: air temperature data were downloaded from the Danish Meteorological Institute (http://www.dmi.dk/en/vejr/); ocean temperature data were freely available from the TOPAZ dataset (http:// topaz.nersc.no); and sea-ice concentration data were available from the US National Ice Centre (http://www.natice. noaa.gov/). We are grateful to Stuart Dunning and Stewart Jamieson for helpful comments during M.Phil. submission.

\section{AUTHOR CONTRIBUTIONS}

$\mathrm{CB}$ designed the study, with input from $\mathrm{RC}$, and led the writing of the manuscript. RC, NR and PN provided input on both the manuscript and the figures. RK carried out the change point analysis and provided input on the statistical analysis.

\section{REFERENCES}

Amundsen JM and 5 others (2010) Ice melange dynamics and implications for terminus stability, Jakobshavn Isbrae, Greenland. J. Geophys. Res., 115

Bondzio JH and 6 others (2016) Modelling calving front dynamics using a level-set method: application to Jakobshavn Isbræ, west Greenland. Cryosphere, 10,13

Carr JR, Stokes C and Vieli A (2013) Influence of sea ice decline, atmospheric warming, and glacier width on marine-terminating outlet glacier behaviour in northwest Greenland at seasonal to interannual timescales. J. Geophys. Res., 118, 1210-1226

Carr JR, Stokes C and Vieli A (2014) Recent retreat of major glacial outlets on Novaya Zemlya, Russian Arctic, influenced by fjord geometry and sea ice conditions. J. Glaciol., 60(219), 155-170

Carr JR and 9 others (2015) Basal topographic controls on rapid retreat of Humboldt Glacier, northern Greenland. J. Glaciol., 61(225)

Carr JR, Stokes C and Vieli A (2017) Threefold increase in marine-terminating outlet glacier retreat rates across the Atlantic Arctic: 1992-2010. Ann. Glaciol., 58(74)

Chapuis A and Tetzlaff T (2014) The variability of tidewater-glacier calving: origin of event-size and interval distributions. J. Glaciol., $\mathbf{6 0}(222)$

Eckley IA, Fearnhead P and Killick R (2011) Analysis of changepoint models. In Barber D, Cemgil AT and Chiappa S, eds. Bayesian time series models. Cambridge University Press, Cambridge, 203-224.

Enderlin EM, Howat I and Vieli A (2013) High sensitivity of tidewater glacier outlet dynamics to shape. Cryosphere, 7

Enderlin EM and 5 others (2014) An improved mass budget of the Greenland ice sheet. Geophys. Res. Lett., 41, 866-872 (doi: 10.1002/2013GL059010)

Fettweis $X$ and 6 others (2013) Estimating the Greenland ice sheet surface mass balance contribution to future sea level rise using the regional atmospheric climate model, MAR. Cryosphere, 7

Goelzer H, Robinson A, Seroussi H and van de Wal RSW (2017) Recent progress in Greenland ice sheet modelling. Curr. Clim. Change Rep. Glaciol. Clim. Change, 3, 11

Gudmundsson GH, Krug J, Durand G, Favier L and Gagliardini O (2012) The stability of grounding lines on retrograde slopes. Cryosphere, 6(6), 1497-1505

Hanna E and 8 others (2008) Increased runoff from melt from the Greenland ice sheet: a response to global warming. J. Clim., 21

Hanna E and 6 others (2012a) The influence of North Atlantic atmospheric and oceanic forcing effects on 1900-2010 Greenland summer climate and ice melt/runoff. Int. J. Climatol., 33, 862880 (doi: 10.1002/joc.3475)

Hanna E, Mernild SH, Cappelen J and Steffen K (2012b) Recent warming in Greenland in a long-term instrumental (1881- 
2012) climatic context: I. Evaluation of surface air temperature records. Environ. Res. Lett., 7

Hanna E and 11 others (2013) Ice-sheet mass balance and climate change. Nature, 498, 51

Howat IM and Eddy A (2011) Multi-decadal retreat of Greenland's marine-terminating glaciers. J. Glaciol., 57(203)

Howat IM, Joughin I, Fahnestock M, Smith BE and Scambos TA (2008a) Synchronous retreat and acceleration of southeast Greenland outlet glaciers 2000-06: ice dynamics and coupling to climate. J. Glaciol., 54(187)

Howat IM, Smith BE, Joughin I and Scambos TA (2008b) Rates of southeast Greenland ice volume loss from combined ICESat and ASTER observations. Geophys. Res. Lett., 35(L17505)

Jamieson SSR and 6 others (2012) Ice-stream stability on a reverse bed slope. Nat. Geosci., 5(11), 799-802

Joughin I and 8 others (2008a) Ice-front variation and tidewater behaviour on Helheim and Kangerdlugssuaq Glaciers, Greenland. J. Geophys. Res., 113(F01004)

Joughin I and 7 others (2008b) Continued evolution of Jakobshavn Isbrae following its rapid speedup. J. Geophys. Res., 113 (F04006).

Killick R and Eckley IA (2014) Changepoint: an R package for changepoint analysis. J. Stat. Softw., 58(3), 19

Killick R, Fearnhead P and Eckley IA (2012) Optimal detection of change points with a linear computational cost. J. Am. Stat. Assoc., 107(500), 8

Killick R, Beaulieu C and Taylor S (2016) EnvCpt: Detection of Structural Changes in Climate and Environment Time Series. $R$ package version 0.1.1

Luckman A and 5 others (2015) Calving at tidewater glaciers vary strongly with ocean temperature. Nat. Commun., 6(8566)

McFadden EM, Howat IM, Joughin I, Smith BE and Ahn Y (2011) Changes in the dynamics of marine terminating outlet glaciers in west Greenland (2000-2009). J. Geophys. Res., 116

Meier M and Post A (1987) Fast tidewater glaciers. J. Geophys. Res., 92

Miles BWJ, Stokes CR, Vieli A and Cox NJ (2013) Rapid, climatedriven changes in outlet glaciers on the Pacific coast of east Antarctica. Nature, 500(7464), 563-566

Moon T and Joughin I (2008) Changes in ice front position on Greenland's outlet glaciers from 1992-2007. J. Geophys. Res., 113(F02022)

Moon T, Joughin I and Smith B (2015) Seasonal to multiyear variability of glacier surface velocity, terminus position and sea ice/ice mélange in northwest Greenland. J. Geophys. Res. Earth Surf., 120

Morlighem M, Rignot E, Mouginot J, Seroussi H and Larour E (2014) Deeply incised submarine glacial valleys beneath the Greenland ice sheet. Nat. Geosci., 4

Morlighem M, Rignot E, Mouginot J, Seroussi H and Larour E (2015) IceBridge BedMachine, Version 2. NASA National Snow and Ice Data Center Distributed Active Archive Center, Boulder, CO

Morlighem M, Rignot E and Willis JK (2016) Improving bed topography mapping of Greenland glaciers using NASA's Oceans Melting Greenland (OMG) data. Oceanography, 29(4), 9

Morlighem M and 31 others (2017) BedMachine v3: complete bed topography and ocean bathymetry mapping of Greenland from multi-beam echo sounding combined with mass conservation. Geophys. Res. Lett., 44

Murray T and 10 others (2010) Ocean regulation hypothesis for glacier dynamics in southeast Greenland and implications for ice sheet mass changes. J. Geophys. Res., 115

Murray T and 14 others (2015) Extensive retreat of Greenland tidewater glaciers, 2000-2010. Arct. Antarct. Alp. Res., 47(3), 20

O'Leary M and Christoffersen P (2013) Calving on tidewater glaciers amplified by submarine frontal melting. Cryosphere, 7(1), 119-128

$\mathrm{O}^{\prime}$ Neel S, Pfeffer WT, Krimmel R and Meier M (2005) Evolving force balance at Columbia Glacier, Alaska, during its rapid retreat. J. Geophys. Res. Earth Surf., 110(F3), n/a-n/a
Pẹtlicki M, Cieply M, Jania JA, Prominska A and Kinnard C (2015) Calving of a tidewater glacier driven by melting at the waterline. J. Glaciol., 61(229).

Pfeffer WT (2007) A simple mechanism for irreversible tidewater glacier retreat. J. Geophys. Res., 112

Porter DF and 6 others (2014) Bathymetric control of tidewater glacier mass loss in northwest Greenland. Earth Planet. Sci. Lett., 401, 6

Post A, O'Neel S, Motyka RJ and Streveler G (2011) A complex relationship between calving glaciers and climate. Earth Space Sci. News, 92(37)

Pritchard HD, Arthern RJ, Vaughan DG and Edwards LA (2009) Extensive dynamic thinning on the margins of the Greenland and Antarctic ice sheets. Nature, 461, 4

Raymond C (1996) Shear margins in glaciers and ice sheets. J. Glaciol., 42(140), 12

Rignot E, Braaten D, Gogineni SP, Krabill W and McConnell JR (2004) Rapid ice discharge from southeast Greenland glaciers. Geophys. Res. Lett., 31

Rignot E, Koppes M and Velicogna I (2010) Rapid submarine melting of the calving faces of west Greenland glaciers. Nat. Geosci., 3

Rignot $\mathrm{E}$ and 9 others (2016a) Bathymetry data reveal glaciers vulnerable to ice-ocean interaction in Uummannaq and Vaigat glacial fjords, west Greenland. Geophys. Res. Lett., 43, 7

Rignot $\mathrm{E}$ and 12 others (2016b) Modeling of ocean-induced ice melt rates of five west Greenland glaciers over the past two decades. Geophys. Res. Lett., 43, 8

Schoof C (2007) Ice sheet grounding line dynamics: steady states, stability, and hysteresis. J. Geophys. Res., 112

Seale A, Christofferssen P, Mugford RI and O'Leary M (2011) Ocean forcing of the Greenland ice sheet: calving fronts and patterns of retreat identified by automatic satellite monitoring of eastern outlet glaciers. J. Geophys. Res., 116

Slater D, Nienow P, Goldberg D, Cowton T and Sole A (2017) A model for tidewater glacier undercutting by submarine melt. Geophys. Res. Lett., $\mathbf{4 4}$

Sohn H, Jezek KC and van der Veen CJ (1998) Jakobshavn Glacier, west Greenland: 30 years of spaceborne observations. Geophys. Res. Lett., 25(14), 3

Sole A and 6 others (2011) Seasonal speedup of a Greenland marineterminating outlet glacier forced by surface melt-induced changes in surface hydrology. J. Geophys. Res., 116

Straeno F and 7 others (2010) Rapid circulation of warm subtropical waters in a major glacial fjord in east Greenland. Nat. Geosci., 3

Straneo F and 8 others (2012) Characteristics of ocean waters reaching Greenland's glaciers. Ann. Glaciol., 53(60)

Straneo F, Hamilton GS, Stearns LA and Sutherland DA (2016) Connecting the Greenland ice sheet and the ocean: a case study of Helheim Glacier and Sermilik Fjord. Oceanography, 29(4), 11

Sutherland DA and Straneo F (2012) Estimating ocean heat transports and submarine melt rates in Sermlik Fjord, Greenland, using lowered acoustic Doppler current profiler (LADCP) velocity profiles. Ann. Glaciol., 53(60)

Todd J and Christoffersen P (2013) Are seasonal calving dynamics forced by buttressing from ice melange or undercutting by melting? Outcomes from full-stokes simulations of Store Glacier, west Greenland. Cryosphere, 8

Van den Broeke $M$ and 7 others (2016) On the recent contribution of the Greenland ice sheet to sea level change. Cryosphere, 10, 13

van den Broeke MR and 8 others (2009) Partitioning recent Greeenland mass loss. Science, 326(984)

Van der Veen CJ (2002) Calving glaciers. Prog. Phys. Geogr., 26(1), 96-122

Warren CR and Glasser NF (1992) Contrasting response of south Greenland glaciers to recent climatic change. Arct. Alp. Res., 24(2)

Weertman J (1974) Stability of the junction of an ice sheet and an ice shelf. J. Glaciol., 13(67) 
Zhang NR and Siegmund DO (2007) A modified Bayes information criterion with applications to the analysis of comparative genomic hybridization data. Biometrics, 63(1), 10
Zwally J and 5 others (2002) Surface melt-induced acceleration of Greenland ice-sheet flow. Science, 297(5579), 218-222

MS received 27 September 2017 and accepted in revised form 26 April 2018; first published online 22 May 2018 